\title{
THE EFFECTS OF PACK CARBURIZING USING CHARCOAL ON PROPERTIES OF MILD STEEL
}

\author{
Supriyono \\ Dept. of Mechanical Engineering, Faculty of Engineering \\ Universitas Muhammadiyah Surakarta \\ Email:supriyono@ums.ac.id
}

\begin{abstract}
The aim of this research is to study the effects of pack carburizing using charcoal on properties of mild steel. The properties are represented by the results of microstructure, hardness test and tensile test. The carburizing process was conducted in the temperature of $930^{\circ} \mathrm{C}$ which is the austenite temperature of the mild steel. The source of carbon was charcoal. The specimens were held for 2, 3 and 4 hours at the carburizing temperature. The carbon content of the raw amterial was $0.17 \%$. The raw material was hypoeutectoid steel with ferrite and pearlite phases in its microstructure. After the carburizing process, the microstructure can be divided into two zones e.i. case zone and core zone. The case zone consists of hypereutectoid, eutectoid, and hypoeutectoid sub-zone. The core zone is the same as raw material. The longer the holding time will result in the deeper the case zone and the stronger the material.
\end{abstract}

Keywords: Pack carburizing; material properties; ferrite; pearlite; cementite.

\section{INTRODUCTION}

Carburizing is the process of saturating the surface layer of steel with carbon. In accordance with carbon source, carburization is classified as pack carburizing, gas carburizing and liquid carburizing. The main purpose of the carburizing process is to have a hard and wear resistance surface on mechanical components by enrichment of the surface layer with carbon to a concentration from 0.75 to $1.2 \%$. Low carbon steels, containing from 0.1 to $0.18 \%$ carbon, may be subjected to carburizing [1]. Many researches have been conducting on carburizing process. Examples of research on carburizing can be found in the work by Aramide et.al.[2], Oyetunji and Adeosun[3], Ihom et.al.[4], Swapnil[5], Priyadarshini et.al. [6], Supriyono and Jamasri[7] .

Investigation was conducted by Aramide et.al.[2] into the mechanical properties of mild steel subjected to packed carburization treatment using pulverized bone as the carburizer. It was observed that the mechanical properties of mild steels were found to be strongly influenced by the process of carburization, carburizing temperature and soaking time at carburizing temperature. The work by Oyetunji and Adeosun[3] evaluates the suitability of using palm kernel shell, animal bone (mammalian bones from cattle) and sea shell (oyster shell) materials as carburizers for case hardening of $0.078 \% \mathrm{C}$ mild steel. The results of the carbon analysis show that palm kernel shell and animal bone are potentially suitable to be used as a carburizing media than the sea shell at high temperatures (above $1000^{\circ} \mathrm{C}$ ) with holding time above $1 \mathrm{hr}$.

Similar research by Oyetunji and Adeosun[3] is the works by Ihom et.al.[4]. The work has investigated the potential of some organic waste materials for surface hardness improvement of mild steel. Waste organic materials like sugar cane, rice husks, egg shell, melon shell, arecaceae flower droppings, plastics, polyethylene, and charcoal were used during the 
reserach. The results have established the potentials of waste organic materials for surface hardness improvement of mild steel. The waste organic materials used in the casehardening media all showed improvement in the hardness values of the mild steel specimens over the $30 \mathrm{HRC}$ hardness value of the untreated mild steel specimen.

Pack carburization uses solid carburizing compounds made up of charcoal and energizer as the carbon source. The common commercial energizer used in pack carburizing are $\mathrm{BaCO}_{3}, \mathrm{Na}_{2} \mathrm{CO}_{3}$, and $\mathrm{CaCO}_{3}$. Over the years, the efficacy of different energizers has been tested. Okongwu and Paranthaman[8] carried out a research to assessed the efficacy of some naturally occurring mineral carbonates in pack carburizing as energizer. In the work, he concluded that it was possible to substitute the commercial carbonates with the naturally occurring mineral carbonates.

A study to investigate the effect of the holding times of pack carburizing process on fatigue characteristic of v-notch shaft steel specimens was conducted by Supriyono and Jamasri[7]. The carbon source was taken from charcoal of unused mahogany. The holding times were 2, 3 and 4 hours. The results showed that the holding time of the carburizing process influences the fatigue strength of the material. The longer the holding time will be the higher the fatigue strength.

This research is to study the effects of pack carburizing using charcoal on properties of mild steel. The properties are represented by the results of microstructure, hardness test and tensile test. In Solo Raya Region of Central Java Indonesia, wood is the most common material to produce many kinds of export quality furniture. This production process leaves alots of unused wood that can be made charcoal. One of the benefits of the charcoal is to be used as carbon souce in pack carburizing[4]. However, the affectivity needs to be studied.

\section{METHODOLOGY}

\section{Material}

The materials used for this work included, steel rods of $16 \mathrm{~mm}$ diameter and carburizing compound of $80 \%$ of charcoal and $20 \%$ of natrium carbonate $\left(\mathrm{Na}_{2} \mathrm{CO}_{3}\right)$ mixture. The composition of the steel used is shown in Table 1.

Table 1. Composition of the steel rod

\begin{tabular}{cccccccccc}
\hline $\mathrm{Fe}$ & $\mathrm{C}$ & $\mathrm{Si}$ & $\mathrm{Mn}$ & $\mathrm{Cr}$ & $\mathrm{Mo}$ & $\mathrm{Ni}$ & $\mathrm{Al}$ & $\mathrm{Cu}$ & $\mathrm{S}$ \\
\hline 98.8 & 0.17 & 0.033 & 0.551 & 0.077 & 0.004 & 0.129 & 0.001 & 0.115 & 0.033 \\
\hline
\end{tabular}

\section{Pack Carburizing Process}

A large muffle electric furnace with a temperature sensitivity of $\pm 5^{\circ} \mathrm{C}$ was employed. The pack boxes were placed into the muffle furnace. The pack boxes and the furnace were heated to reach carburizing temperature of $930^{\circ} \mathrm{C}$. At the carburizing temperature, the process was held for 2, 3, and 4 hours.

\section{Microstructure}

Microstructure was carried out on both the uncarburized material or raw material and the carburized material.

\section{Hardness test}

The hardness test was conducted on carburized material to determine the effective case depth. Microhardness measurements were carried out along the cross sectional area on the distances of $50,100,200,500,700,1000,1250$ and $2000 \mu \mathrm{m}$ from the surface at three different places. The hardness number of every distance is the average of the three values. 


\section{Tensile test}

Tensile test is conducted according to standard of JIS Z220 14Afor rod specimen.

\section{RESULTS AND DISCUSSION}

Based on the Table 1, the carbon content of the steel rod is $0.17 \%$. It indicates that the raw material is in the family of low carbon steel[9]. Low carbon steel is often used as the material of gear, chamshaft, bushing and madrel after case hardening. The microstructure of low carbon steel consists of ferrite and pearlite. Figure 1 shows the microstructure of the raw material. The light area is ferrite, whereas the dark area is pearlite. The light area is dominant one since the carbon content is $0.17 \%$.

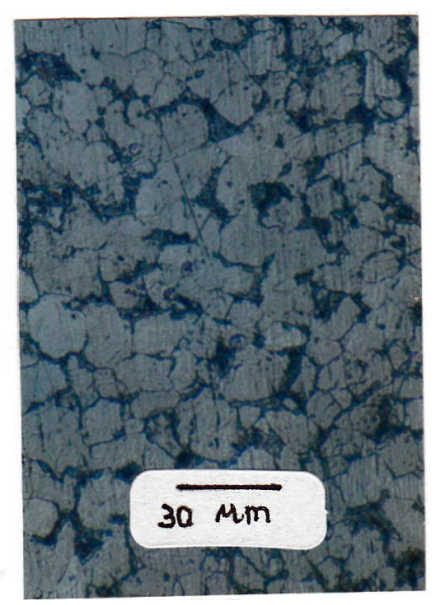

Figure 1. Microstructure of the raw material

The micro structures after carburizing process can be seen in the Figure 2 and Figure 3. From Figure 2, it can be seen that the microstructure after carburizing is devided into 2 zones i.e. case zone and core zone. The core zone has the same micro structure as the raw material, whereas the case zone can be devided into three sub-zones[10]. The three sub zones are hypereutectoid, eutectoid and hypoeutectoid. Hypereutectoid sub-zone (see Figure 3.c) has micro structures of pearlite and proeutectoid cementite. Eutectoid sub-zone has micro structure of pearlite (see Figure 3.b). And hypoeutectoid sub zone has micro structure of ferrite and pearlite (see Figure 3.a).

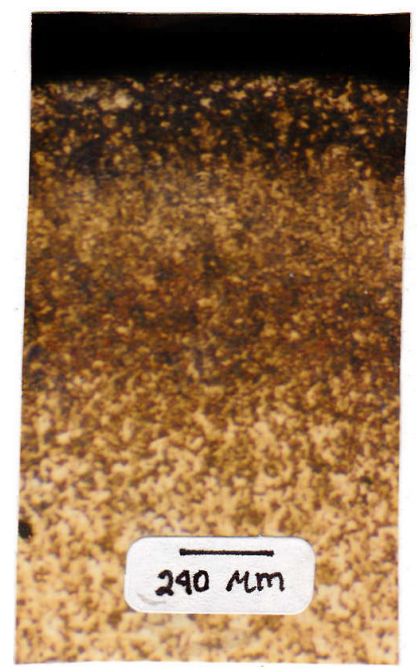

Figure 2. Micro structure of carburized material 


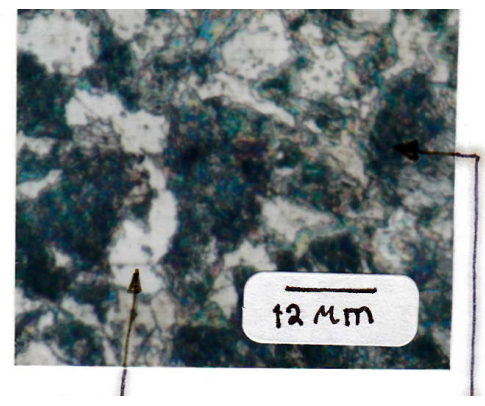

Ferrite

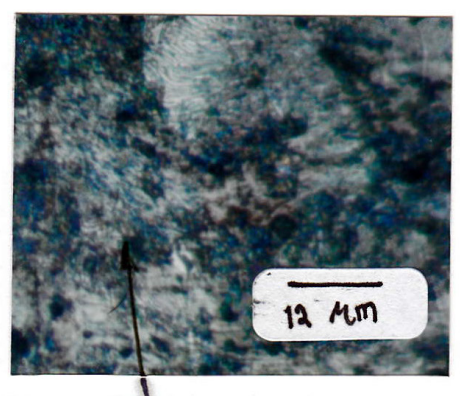

Pearlite

(a)

(b)

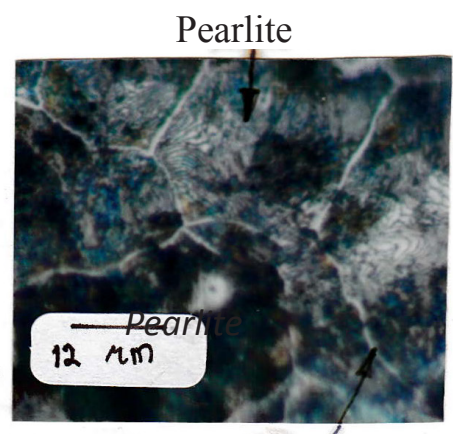

Cementite

(c)

Figure 3. Micro structures of case zone: (a) hypoeutectoid sub-zone, (b) Eutectoid sub-zone, (c) hypereutectoid sub-zone

Figure 4 shows the hardness profile of carburized material of each holding time ( 4,3 and 2 hours). The hardness profile has the shape rising on the left and descending on the right indicating that the hardness of the carburized steel specimen decreases as it move towards the core of the steel. This is typical of all carburized steels; a hard case and a soft cor. It can be seen that the longer the holding time is the harder the surface zone. It indicates that more carbon in the surface zone for the longer holding time.

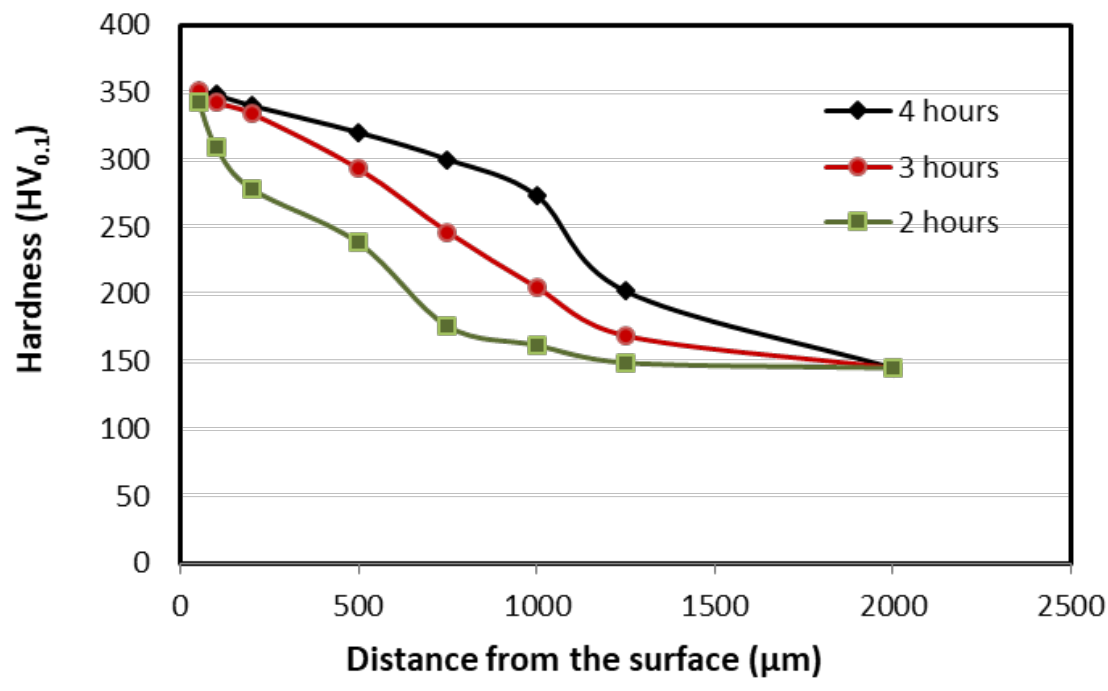

Figure 4.Hardness profile of carburized material.

Table 2 is the result of tensile test. It can be seen that in term of yield stress the raw material has the highest value compared to the carburized ones. This is due to strain hardening during the forming to the final shape of the raw material. The raw material is the rod with diameter of $16 \mathrm{~mm}$. To have the final shape, it experienced large plastic deformation. The yield stress is obtained by offset method. For the carburized material, the longer the holding time is the stronger both for the yield and ultimate stress. This indicates that the longer the holding time will increase the carbon content that increases the strength of the carburized material.

The raw material is very ductile material as shown by the elongation. It is the property of mild steel. They are soft and very ductile. On the other hand, the more carbon content with the longer holding time will decrease the ductility of the carburized material. 
Table 2. The results of tensile test.

\begin{tabular}{|l|c|c|c|}
\hline \multicolumn{1}{|c|}{ Specimen } & $\begin{array}{c}\text { Yield Stress } \\
\text { (Mpa) }\end{array}$ & $\begin{array}{c}\text { Ultimate Stress } \\
\text { (Mpa) }\end{array}$ & $\begin{array}{c}\text { Elongation } \\
\mathbf{( \% )}\end{array}$ \\
\hline Raw Material & 616.68 & 636.84 & 26.84 \\
\hline Carburized 2 hours & 357.23 & 597.34 & 24.56 \\
\hline Carburized 3 hours & 382.05 & 623.89 & 23.7 \\
\hline Carburized 4 hours & 411.54 & 681.36 & 21.66 \\
\hline
\end{tabular}

\section{CONCLUSION}

The carburizing process using charcoal of unused wood changes the properties of the mild steel. The changes in this research represented by the changes of microstructure, hardness and tensile strength. The microstructure of the carburized mild steel can be divided into two zones e.i. case zone and core zone. The case zone consists of hypereutectoid, eutectoid, and hypoeutectoid sub-zone. The core zone is the same as raw material. The longer the holding time will result in the deeper the case zone and the stronger the material.

\section{AKNOWLEDGEMENT}

This work is supported by Research Institute of Universitas Muhammadiyah Surakarta.

\section{REFERENCE}

[1] J. K. Ahmad, “Carburizing of steel,” Int. J. Mater. Sci. Appl., vol. 4, pp. 11-14, 2015.

[2] F. O. Aramide, S. A. Ibitoye, I. O. Oladele, and J. O. Borode, "Pack carburization of mild steel, using pulverized bone as carburizer: Optimizing process parameters," Leonardo Electron. J. Pract. Technol., vol. 9, no. 16, pp. 1-12, 2010.

[3] A. Oyetunji and S. O. Adeosun, "Effects of Carburizing Process Variables on Mechanical and Chemical Properties of Carburized Mild Steel," J. Basic Appl. Sci., vol. 8, pp. 319-324, 2012.

[4] A. P. Ihom, G. B. Nyior, O. O. Alabi, S. Segun, J. Nor Iv, and J. Ogbodo, “The Potentials of Waste Organic Materials for Surface Hardness Improvement of Mild," Int. J. Sci. Eng. Res., vol. 3, no. 11, pp. 1-10, 2012.

[5] P. B. D. D. Swapnil R. Nimbhorkar, "Effect of Case Hardening Treatment on the Structure and Properties of Automobile Gears," Int. J. Mod. Eng. Res., vol. 3, no. 2, pp. 637-641, 2013.

[6] S. Priyadarshini, T. Sharma, and G. Arora, "Effect of Post Carburizing Treatment on Hardness of Low Carbon Steel," Int. J. Adv. Mech. Eng., vol. 4, no. 7, pp. 763-766, 2014.

[7] Supriyono and Jamasri, "Holding time effect of pack carburizing on fatigue characteristic of v-notch shaft steel specimens," in AIP Conference Proceedings, 2017, vol. 1855.

[8] D. A. Okongwu and V. Paranthaman, "Assesment of The Efficacy of Some Carbonate Minerals as Energizers in Pack Carburisation of Mild Steel," Niger. J. Technol., vol. 11, no. 1, 1987.

[9] H. C. ASM, Metals Handbook, 8th ed. Ohio, 1972.

[10] Y. Lakhtin, Engineering Physical Metallurgy. Moscow: Foriegn Language Publishing House, 1965. 